\title{
Zoofolkloristics: First Insights towards the New Discipline
}

\author{
MARJETKA GOLEŽ KAUČIČ \\ Institute of Ethnomusicology ZRC SAZU
}

\begin{abstract}
The author notes that new, more complex researches of connections between animals, nature and connections to humans are needed in Slovenian and European folklore, literature and cultural studies, due to new ecological and ethical findings in the wider social and cultural environment and a changing order of the world, which has moved the focus from anthropocentrism into ecocentrism. The discussion builds upon various theoretical discourses, new concepts and multidisciplinary knowledge, to create the foundations, guidelines and directions for a new academic discipline of zoofolkloristics. Furthermore, new theoretical and analytical discourses should enable zoofolkloristics to provide an insight into changes in human attitudes to animals, in both folklore and within traditional and contemporary ritual practices, or their redefinition, and at the same time exert influence upon legal safety of nonhuman subjectivities.
\end{abstract}

Key words: zoofolklore, zoofolkloristics, animals in folklore and literature, anthropocentrism, ecocentrism, critical animal studies

A man has to overcome the power of symbols. Animals do not need an awareness of evil, while people do, to renounce their crimes. (Jure Detela, Orfični dokumenti I / The Orphic Documents I)

\section{INTRODUCTION}

The purpose of this article is to determine whether a newly founded academic discipline, zoofolkloristics, ${ }^{1}$ which introduces a new theoretical and analytical discourse, can enable us to reach insight into changes in human at-

\footnotetext{
${ }^{1}$ As the author has been intensively engaged in research on animals in folklore and literature since 1999, the bibliography lists all published articles and chapters on this topic by the author $(2002 \mathrm{a}, 2002 \mathrm{~b}$, 2004, 2011a, 2011a, 2011b, 2012a, 2012b, 2013a, 2013b). These are used by the author as a building foundation for further development of the concepts of zoofolkloristics, ecocriticism or ecocultural research.
} 
titudes to animals in both folklore and within traditional and contemporary ritual practices, or their redefinition, and at the same time exert influence upon legal safety of non-human subjectivities.

Many of our basic research ideas and findings about nature and animals originate in ancient myths and folklore tradition. The accumulated tradition in various forms of folklore can ultimately bring about a different understanding of ecology, especially during the period of modern technology, in which Daniel Botkin's claim² that ecologists need the help of folklore specialists is used as a basis.

Due to new ecological and ethical (bioethical) ${ }^{3}$ findings, such as a new perception of the environment and new ecological ethics, which fosters responsibility towards the environment, people and all living creatures both within the wider social and cultural context and the changed state of the world (with an epistemological paradigm shift, Kuhn 2012/1962), which ultimately caused the focus to shift from anthropocentrism to ecocentrism, Slovenian and European research also requires urgent research of both animals (zoofolklore, ethnozoology, ecocriticism) and nature (ecofolklore, ecopoetics, ethnobotany, cultural botany) and human relations towards them in folklore, literature, and culture. Multidisciplinary findings of these studies might redefine the relations between people, animals, nature and the environment on new ecological and ethical bases (that animals and plants are important in and of themselves).

Consideration should touch upon differences between a human and an animal, the ethical and ontological status of animals, and overcome the distinction on the basis of new knowledge and political practices. According to Hösle, we are on the threshold of a new moral and political paradigm - a (new) ecological paradigm (1996: 26; Dunlap 2000) - and so not only business, but also other disciplines and especially the humanities are to contribute to this. In this regard, ethnology, folklore studies, and literary studies could play an important part in developing ecological awareness, which is why it would make sense to introduce new notions with the prefix eco- or to develop both the field of research and study of cultural ecology; what is also involved is making a shift from ecology to eschatology (Grčević 2002), because, for example, those who write poetry can no longer ignore the "substance" of the world. According to Taylor (1986), from the viewpoint of biocentric equality, all organisms, regardless of their species, have the same internal value and right to be treated respectfully. In this way researchers have already started their journey towards biocentrism and ecocentrism.

2 See Botkin Daniel. "The folklore behind ecology, or why scientists of ecology need help from folklorists". The American Folklife Center, 5. 4. 2006. http://www.loc.gov/folklife/events/ BotkinArchives/2006PDFandVideo/BotkinFlyer.pdf.

${ }^{3}$ See Charlton and Francione (1992); James (1997); Klampfer (2010). 
Similar issues could be raised with respect to plants and nature as a living organism. ${ }^{4}$ Despite the fact that every animal (including the human animal) is, in addition to being part of nature, also a part of culture, our attitude towards other animals remains distinctly hierarchical, which is also the case in folklore and literature, with the animal being "culturally ousted" (Zapf 2002; Čeh Steger 2010: 54). However, it is very important that zoofolkloristics research should not be isolated from other researches, hence the term ecofolkloristics could be used as an expanded label representing all research on animals, nature and plants.

\section{TOWARDS ZOOFOLKLORISTICS: QUESTIONS, THOUGHTS, CONCEPTS}

The discussion in this article will focus on an entirely new discipline within folkloristics, i.e. zoofolkloristics. What is zoofolkloristics? Can zoofolkoristics in its essence be simple? Or is it multifaceted? Is it just about people's knowledge of animals reflected in songs, stories, traditions and beliefs? Or is zoofolkloristics much more than that today? After all, apart from "zoolore", it also contributes to the critical discourse of the aforementioned knowledge of animals, which is not only very informative as to the coexistence of people and animals, but also describes relations and practices which are no longer acceptable. Therefore, the introduction of a "new" discipline requires that views on the subject matter be classified based on critical discourse. The simplest definition of zoofolkloristics defines it as a discipline dealing with animals in folklore. However, this definition is generalised and oversimplified. We need to find out how an animal is seen today and how it was seen in the past, as it is this diachronic perspective which enables adequate research into and interpretation of folkloric works from Middle Ages until today. These works are a part of the past, a part of tradition and a part of cultural and social circumstances and constructs which differ from those in the present. In fact, some traditions and cultural practices have been virtually "frozen in time".

First, we need to define who (or what) an animal was in the past and what (or who) it is today, which means we need to take into account past and present views on the animal in question. Moreover, a critical perspec-

${ }^{4}$ I can not ignore Montaigne, who wrote in his Essays that humans are obligated to respect animals, as well as trees and plants (1960: 130). Besides zoofolkloristics, research in botany, folk botany, ethnobotany and the whole environment as a holistic scientific approach to nature is especially important in the studies of folk traditions. Based on the established discipline of ethnobotany (Balée in Brown 1996), Visković (2001: 31) pointed to the lack of research on the role and importance of plants in myths (mythical botany), customs, beliefs, in the arts and in political symbolism (e.g. the tree of life). 
tive on folklore is essential to the introduction of the new discipline. This perspective would allow us to see an animal in folklore as a part of culture, as opposed to a part of nature, from a perspective informed both by the position of animals in the modern world, and by new findings on the human and the animalistic. This offers an opportunity for the reconstruction of the past, as well as one for its deconstruction. Therefore, we first need to answer the questions, "What was an animal then? And what is it today?" We are not interested in a biological definition but rather in a cultural one. The question "What is an animal?" itself, as asked by editor Tim Ingold in the collection of articles in the book of the same name, points to the fact that an animal is not a person, otherwise Ingold would use "who"- "Who is an animal?". Despite this, he does note in the preface that every animal form is caught up in the life process and is not a priory part of a species. He stipulates that animals are not like persons, they are persons: "Now the ontological equivalence of humans and animals, as organism-persons and as fellow participants in a life process, carries a corollary of capital importance" (Ingold 1994: XXIV). However, the Western world has not been able to accept this view. In Kulturni bestijarij, the editors base their perception of animals on different concepts of animals: animalis - alive; animus - spirit; anima - soul, air, life force, living being; animal - animal (Zaradija Kiš and Marjanić 2007: 11). In different contexts the word is given different meanings, sometimes pejorative ones, for example it can denote a bad person. The word animal is therefore contrary to the word human, which consequently creates a clear divide between the two words and between their meanings. In folklore there has always been a distinction between the concepts of "animal" and "human" when it reflects reality, whether in songs, stories or pictures. However, there are some narratives in which this distinction is disregarded. In such fairy-tale and mythological depictions, transitions from human to animalistic and back, and even marriage between animals and humans (described by Sax as a marriage of human and natural (1998: 10)), are possible. Who or what is human in relation to animal and vice versa? Considering the predominantly ambivalent approach towards animals in the past it has been suggested by Serpell that people did have an attitude towards animals, but it was always superior or expressing the man's dominion and supremacy (1986: 213-236). It derived from philosophical (from Aristotle, Descartes, ${ }^{5}$ Kant, Marx etc.) and religious (Christian-Jewish e.g. Thomas Aquinas, John Calvin ${ }^{6}$ ) perspectives, and most frequently relied on ideological concepts of animals where a majority of these authors considered animals lower beings with no feelings and emotions, making humans their a primary concern, although it does seem that

\footnotetext{
${ }^{5}$ See Kalof and Fitzgerald (2007: 5-8); (57-59); Serpell (1996); Darwin (1872); Nietzsche (1989: 28).

${ }^{6}$ See Hobgood-Oster (2007: 190-191); Willis (1990: 6).
} 
different species of animals warranted very different attitudes, reinforced by superstition and the different positions that the animals had within the microcosm of humans in folklore. At least two early historical texts that discuss the relationship between animals and humans talk about the superiority of animals, not humans. The first one is by Pliny the Elder, who wrote in his Natural History (Naturalis Historia is an early encyclopaedia published circa AD 77-79):

All other [underlined by the author] animals know their own natures. Some use speed, others swift flight, and the yet others swimming. Man, however, knows nothing unless by learning without learning - neither how to speak nor how to walk nor how to eat; in a word, the only thing he knows instinctively is how to weep. (Pliny, Natural History, book 7, chapter 1, quoted in Sax 1998: 17)

The second text is a medieval work Rasa'il Ikhvan al-Safa, an Arabic encyclopaedia written in the $10^{\text {th }}$ century, specifically, its $51^{\text {st }}$ epistle ("Conversation of man with animals") discussing the meeting of species (cf. Ihvanus-sSafa 2008). Rasa'il Ikhvan al-Safa (Encyclopedia of the Brethren of Purity) was written by the mysterious Brethren of Purity of Basra. It is a literary, philosophical and spiritual work, a monument of Muslim provenance, which also includes extracts from the Old Testament and the New Testament. It intertwines insights from the Quran with those from the Bible, and with the knowledge and philosophy of classical antiquity. The treatise presents a dispute between humans and animals, with humans attempting to prove their superiority, which the animals cleverly challenge with their concise arguments. They discuss how human or non-human subjectivity presents itself; knowledge that humans can only obtain by learning while animals' knowledge is innate. The text includes exceptional descriptions of the lives of bees, termites, spiders, swallows and other animals and of their aptitude ${ }^{7}$ when building their homes or healing themselves. In contrast, humans struggle to learn skills (ibid.: 10). It also shows that even in the animal world there are certain cultural patterns and skills, even crafts, and that knowledge is not only predestined biologically but also encompasses creativity.

However, what is the attitude of humans towards animals? Is it personal or impersonal? Could we possibly say that the attitude of animals to humans is personal (fear, curiosity, terror)? We can see from folklore that in the

${ }^{7}$ Montaigne believed that animals are better at certain things than humans: when in danger, oxen, pigs and other creatures form groups. Schools of tuna have been known to form perfect squares, which means that they understand geometry and arithmetic. A kingfisher can build a structure out of bones that serves both as its nest and as a boat, so the bird can test it on the shore before setting off to sea (Montaigne 1580, quoted in Bakewell 2014: 118-123). 
past, a personal attitude to animals was expressed more often than in the present, since people lived close to animals. Slovenian folk tradition points to the fact that in the past the peasant considered the animal a sentient being, a comrade and a friend - particularly given that they often depended on animals for their survival (Coy 1988; Kuret 1989; Ingold 1994). However, this has changed substantially with changes in the political order, turning animals from beings into means of production. In the pre-industrial era, knowledge about animals was widespread, as people depended on the wellbeing of animals. Today this knowledge is limited to the population living in the countryside, and even they have introduced technology and forgotten a lot of traditional knowledge. Consequently, a lot of traditions from people's beliefs, along with the strong connection humans once had with animals, have been lost (see Golež Kaučič 2002b, 2011b). In pre-industrial societies, animals were kept for food and clothing, but they still lived in a more or less acceptable environment, and usually died by human hand, the same human hand that fed them. Even in death they were treated individually, each being an individual in itself. In the words of Juliet Clutton-Brock:

Everyone who reared a new-born lamb or milked a cow knows that every animal is different [...] In "olden times" people lived close to their animals (livestock), sometimes they would share a space, and even though they could be very cruel, they still treated animals as individuals that could suffer just as people could. (Clutton-Brock 2006: 33)

It is interesting to note that the transition from feudalism to industrialism coincides with the beginnings of discussions on animal rights, appropriate living conditions, life and suffering:

Urban and industrial society depends on animal products from battery or industrial farms, where animals are reduced to machines. They live in artificial conditions and the owners' only concern is profit based on the cost-effective organization of animals' production and reproduction. This is of course a classic exploitative capitalist approach. (Tapper 1994: 53, see Serpell 1996: chapter 11)

In the industrial era, the animal becomes an object of mass production, slaughtered in catastrophic conditions and treated sadistically, and is ultimately delivered to consumers (who do not think of it as a being that was once alive) in the form of packaged meat. ${ }^{8} \mathrm{~A}$ personal stance in relation to

\footnotetext{
${ }^{8}$ According to Steiner, Plutarch "defended animals", cognitive abilities among classical period thinkers" (Steiner 2005: 42). This attitude is especially apparent in his work, On the Eating of Flesh (De esu carnium), written during the period in which Plutarch supported the abilities and moral status of
} 
animals is present in some folklore texts (connected to agricultural life in the $18^{\text {th }}$ and $19^{\text {th }}$ century) and also in practices, customs and rituals. ${ }^{9}$ This stance is reflected in texts and in people's statements, ${ }^{10}$ in the names domestic animals were given and in the respect shown to wild animals despite the fact that they were hunted. At the same time, there was no awareness of animal rights. Everything was made to accommodate human beings, and animals were people's property. However, the proximity of animals did facilitate an understanding of animals as living beings. Individual treatment of animals is very much present in folklore, although animals in songs and narratives appear as members of individual species. We need to look at folk tradition which, apart from its cruel treatment of animals, talks about a relatively positive co-existence between humans and animals (see Kuret 1989; Golež Kaučič 2002b, 2011b, 2012a).

However, we are still talking about a predominantly anthropocentric view of animals. In the past, this view could be defined as a combination of two concepts (which also appear in folklore). Firstly, the synanthropic principle that animals are harmful, and secondly, the anthropophilic principle that animals are useful. ${ }^{11}$ These two concepts are still in use, although they have developed in parallel in society, changing accordingly over time. However, in the past, the anthropocentric principle had been repeatedly rejected, but only until the spread of the Cartesian worldview. Human history records several cases where people and animals were considered to be equal, as seen in the so-called animal justice courts, active between the $13^{\text {th }}$ and $18^{\text {th }}$ centuries (Ferry 1998: 9). Nowadays, people are alienated from other beings, especially from those they use, to such extent that not only do they remain alienated, but they also refuse to acknowledge animal suffering. They accept this situation as a given without any ambition to overcome it. ${ }^{12}$ People's "view" of animals is closely related to their physical proximity to them, and at the same time with their alienation from them. At least two concepts are at work here:

animals, and promoted the responsibility of humans to be fair and not to use animal body parts for their own nutrition, for spiritual, religious, anthropological, physionomic and ethical reasons (Plutarch, De esu carnium, quote from Vičar 2013: 137).

${ }^{9}$ Montaigne loved telling animal stories, and borrowed many from Plutarch. He believed that animals are just as noble as humans. He mentions the female kingfisher's fidelity; if necessary she can faithfully carry a wounded male bird on her shoulders until his death (Montaigne 1580, quoted in Bakewell 2014: 118-123).

${ }^{10}$ E.g. a farmer from Pivka says to his ox: "You are smarter than a man", meaning that the importance of a work animal to a farmer used to be immeasurable (Smerdel 2006: 367).

${ }^{11}$ Cicero says that "Barbarians idolize animals for their benefits" (Cicero, quoted in Montaigne 1960: 131).

12 This includes pets, e.g. cats and dogs, which are considered to be our companions, whether they wish to be or not, since they were domesticated in the past. Categorizing domesticated animals as those being used and those that are not used is the topic of the book by Melanie Joy Why We Love Dogs, Eat Pigs, and Wear Cows; An Introduction to Carnism (2010). 
considerable proximity in the past and marked alienation in the present. According to Hacking, the two are linked by the human concept of deflection; people averting their eyes in order not to look at the way they treat animals (Cavell et al. 2008: 146). The theoretician Cavell calls our inability to see the Other that is in the shape of an animal as "a sort of "blindness of the soul"' (ibid.: 92-94). Furthermore, Serpell states that:

it is not so much that we avoid killing animals with which we are friendly. It is more the other way around. Unconsciously or deliberately we either avoid befriending the animals we intend to harm, or we fabricate elaborate and often mythological justification for their suffering that absolve us of blame. (Serpell 1996: 210-211)

Two other predominant concepts can be found in folklore, i.e. anthropomorphism, whereby animals are attributed human characteristics (it is strongly apparent in folk songs: a cat is so unhappy because of an unrequited love that it hangs itself, the wolf is brutal, the dog is dirty, etc.) or otherwise behave like people - animals are transferred into the human world (e. g. a cunning fox). The second is zoomorphism, whereby animalistic characteristics are attributed to people (a man is as brave as a lion). Visković believes that:

if attributing nobility and bravery to a lion and cunningness to a fox is an instance of anthropomorphism, as these are psychological characteristics of humans, then the opposite can be said of characterizing people as noble as lions or as cunning as foxes, which is actually zoomorphism, reflected in and hiding behind anthropomorphism. (2009: 55)

Lockwood lists five types of anthropomorphism, which can be used to determine the human perceptions of animals in fables and other literary texts. We are interested in the first and the fifth types. The first type is allegoric anthropomorphism, which is a way in which a story or message is made either more hidden or more likable. Lockwood mentions two modern fables, Watership Down (1972) by Richard Adams and Animal Farm (1945) by George Orwell. Such anthropomorphism does not represent a threat since the animals depicted are not real. The fifth type is known as applied anthropomorphism, whereby we can apply our own experience and try to empathise with others, or try to determine what it means to be a member of a different species (Lockwood 1989: 41-56). As zoofolkloristics focuses on multidisciplinary research, we can, when researching our theoretical basis, refer to various discourses on animals and humans. These go beyond folkloristic or even philosophical discourse (this article takes into account the discourse of Deleuze and Guattari (2000: 27), who introduced the concept "devenir-l'animal" i.e. becoming an animal, Derrida (The Animal That 
Therefore I Am, 2002), encompassing anthropologic and critical animalistic discourse, and even going beyond to legal discourse and other discourses. For example, Garry Francione (2000: 151-153) believes that today the question is not one of whether animals suffer, or feel - it is one of their interests in life. ${ }^{13}$ However, in order to realise this, people need to stop thinking about them as property, which means setting them free from slavery. We are looking at an abolitionist theory, which takes human experience and transfers it into the animal world. This however, ceases to be merely an ethical matter, and becomes a legal matter too. The ethical credo in zoofolkloristics is supposed to be non-anthropocentric, and based on not discriminating against the Other on the basis of species. We can also take advantage of the theory of speciesism, which is actually an ideology which discriminates based on species, excluding animal species due to structural differences. The discrimination is socially enacted and gives the human being superior value. Joan Dunayer points out that speciesism can be observed on the linguistic level, e.g. "the pig was slaughtered and the horse died". She also believes that the phrasings "a bird in a cage, a dog on the leash, a fish in the pond", often used in folklore texts and everyday language, are further examples of speciesism ${ }^{14}$ (2009: 29). Apart from philosophical discourse, we mustn't forget the findings of ecocriticism (Glotfelty 1996; Zapf 2002, 2008; Čeh Steger 2012). We can agree with Zapf, who believes that the relationship between literature and culture can be called "ecological", since

it is a textual form which breaks up ossified social structures and ideologies, symbolically empowers the marginalized, and reconnects what is culturally separated. In that way, literature counteracts economic, political or pragmatic forms of interpreting and instrumentalizing human life, and breaks up onedimensional views of the world and the self, opening them up towards their repressed or excluded other. (Zapf 2002: 5)

${ }^{13}$ The Slovenian tradition of slaughtering, which happens at least twice a year and during which mostly pigs are slaughtered, is considered a folk tradition and a folk holiday. A group of people gathers for the slaughter and to have fun, and subsequently consumes the bodies of the animals. The animal's interest in its life is not of any consequence, it is only human interest that counts. It might be interesting to note that in rural areas, where self-taught butchers did the majority of the slaughtering, people used the phrase "prašič mora umreti" (the pig must die) instead of the words slaughter or slaughtering. This, however, does not justify the action (see Maja Godina Golija 2000: 224-225).

${ }^{14}$ Or in the words of Vičar: "Discursive constructions of animals and human-nonhuman relationships (Stibbe 2001, 2005) show that language on all levels (from lexical to semantic) is systematically connected with hidden ideologies, which preserve and reproduce the oppression and abuse of animals. Metaphors, grammatical structures, pronouns and other linguistic characteristics present nonhuman animals as objects of scientific research, as production machines or as inferior beings. Language is one of the ways we reflect our morally unjustified and discriminatory attitude towards animals. While at the same time, it can be a challenge leading to a change in the moral paradigm" (2011: 510). Marjanić (2012) also discusses speciesism in zoopoetry and the demonisation of animalistic entities, e.g. in literature. 
If we apply this view to folk non-material culture and its traditions relating to the human-animal relationship, we can say that animals are marginalised in folklore and in both folkloristic and ethnological research. Moreover, tradition is holding on to cultural practices that place animals into situations whose interests are subject to human interests. However, in folklore texts we can still find parts where the superiority of humans is not so solid and empathetic relationship towards animals predominate. New concepts within the "ecology niche" where authors propose that the triad literature history - politics (political crisis) should be replaced by an ecological niche (literature - ecosphere, ecological crisis), which expands its ethic towards biophilia and literary ecology (Marjanić 2006: 164) could also be applied to folklore and used to re-evaluate perceptions of folklore, link it to ecology and change human attitudes to non-human beings. The latter is the basic concept of zoofolkloristics.

\section{ZOOFOLKLORE OR ANIMALS IN FOLKLORE}

Based on the previously mentioned concepts, it seems that zoofolkloristics is a very complex discipline that does have a place within folkloristics, but the focus of its research is very specific and goes beyond the framework of classical folkloristics. Consequently, its subject matter and direction of research need to be identified before the discipline can be fully defined. The subject matter are animals in folklore, their presence in all spheres of folk non-material culture; songs, tales, fairy-tales, fables, legends, proverbs and sayings, riddles, jokes, folk language, cultural practices, folk arts and theatre, mythology, folk healing and even folk music. ${ }^{15}$ However, this subject matter is studied from new perspectives, applying new observations and new reception. Zoofolkloristics draws its knowledge from people and their creativity in songs and narratives, their perceptions of the world and their reactions to it. This methodology deals with the relationships between people and animals, the place of animals and their roles in different folklore works. It classifies and defines types of folklore works according to different occurrences of animals and different attitudes people exhibit towards them, all from the perspective of the cognitive classification of animals in folk traditions (Berlin 1992: 8; Ilomäki 2002: 138). Or, according to Ilomäki, "Animal concepts do not require ethnobiological classification, they are explained on the basis of cultural meaning" (2002: 144-145).

${ }^{15}$ The discipline encompasses customs, ritual, habits, celebrations, games, food, folk medicine and folk botany. 
We need to decide whether all research dealing with animals in folklore can be assigned to the field of zoofolkloristics, or only that research which, according to the so-called "ontological shift" in the social sciences, predominantly researches animals as beings in their own right, not as animals in service of humans from the anthropocentric point of view. Zoofolkloristics supposedly abandoned anthropocentrism, although it is still detectable in zoofolkloristic research.

Folklorists and ethnologists, and even anthropologists, have not been particularly interested in researching animals in folk cultures. When such research was conducted, it focused on the motifs/themes, as well as mythological, symbolic and metaphorical aspects. The animal and its role were observed from an abstract perspective only; the animal was not perceived as a living being, merely a symbolic image. Paul Shepard wrote:

Animals are the first inhabitants of human imagination. They are fundamental for the development of speech and thinking. Because of their part in the growth of consciousness, they are inseparable from the series of events in each human life, indispensable to our becoming human in the fullest sense. (Shepard 1978: 2) ${ }^{16}$

The characterisation of the animalistic and the human in folklore texts has stereotyped animals and their distinction from humans ever since the classical period in history, which has negatively affected the attitudes of contemporary people towards animals. Humans used animals to build their own cultural patterns. In the collection of scholarly papers entitled Signifying Animals (Willis 1990: VIII, e. g. Visković 1997: 11-16), it is clearly stated that animals are undoubtedly a part of cultural tradition, and that human relationships with animals are varied; ecological, psychological, cultural and utilitarian aspects are included in the way people behave and treat other beings, how they react upon meeting them, where human and non-human beings can meet as "subjects". These relations have prompted the formation of new ecocriticism of anthropocentrism, establishing new roles for nonhuman subjectivity. According to Boria Sax, every animal is part of tradition and all animals are part of our heritage. He continues, "No animal completely lacks humanity, yet no person is ever completely human" (Sax 2007: 277).

The animal was exploited throughout history as the Western man established a divide between the animalistic and the human based on philosophi-

${ }^{16}$ The example given by Lévi-Strauss in Totemism (1962/1994) shows that animals provide us with thought: through them we can create images of the world, we learn from their behaviour and we are taught by them, and it is the animal image and the animal sound which enable us to imprint into our individual and collective memory ethical norms, as well as moral commitments and empathy towards non-human beings. 
cal concepts, such as Descartes concept of animals as merely machines ${ }^{17}$ incapable of suffering, and based on religious paradigms such as the Christian paradigm that a human is the crown of the Universe. The human was positioned above the animal. The animal was declared to be a marginal being or even an object that was to be enslaved and hunted. Its existence was and is entirely dependent on humans. Species which completely avoided human influence are very rare. This Western idea is distinctly dualistic - humans situated animals firmly in nature and themselves into culture. Or, according to Ingold, the animal is mostly defined as a negation of a human being (Ingold 1994: 3-6). However, this kind of dualism and negation are overcome by conclusions which state that just like humans, animals are part of culture as well as of nature. For example, this is true of nations that do not recognise this concept of duality.

Understanding of the animalistic or the human is part of the perception and social construction of individual cultures, or even part of an "imaginary idea" of separation of animals from humans. The Ojibwa of subarctic Canada believe that the human form is just one of many possible representations a person (a person being a blend of feelings, volition, memory and speech) can materialize in, one of the others being, for example, an animal. That is why they do not connect the concept of person solely with humans (Ingold 2000: 22, quoted in Štuva 2013: 138). Based on his research on South American Indians, the anthropologist Eduardo Viveiros de Castro (1998: 469-488) opens up new possibilities of understanding animals and humans based on the physical and the spiritual, which join rather than separating the two species. At the same time, he offers new possibilities for perception of the human and the animalistic and introduces the concept of new animism.

\section{RESEARCH ON ANIMALS IN CULTURE IN EUROPE AND AROUND THE WORLD: HISTORY AND DIRECTIONS}

In the twentieth century, the research community saw the development of various multidisciplinary directions in the study of animals, nature, and the environment, ranging from sociological, ethological, anthropological, political, and activist animal-rights studies, to ecofeminism, deep ecology, and philosophical and legal perspectives on the relations between people, animals, plants, the environment, and culture. Leading researchers in these fields include Peter Singer, Tom Regan, Paola Cavalieri, Luc Ferry, Boria Sax,

\footnotetext{
${ }^{17}$ Agamben suggests the term macchina antropologica for human as an opposition of anima automata for animals (Agamben 2004: 37).
} 
Barbara Noske, Nikola Visković, Joan Dunayer, Steven Best, Roy Willis, and many others.

In the past, European ethnological and folklore studies only rarely tackled cultural-animalistic and environmental topics; they were first presented in the book Animals in Folklore (James R. Porter and W. M. S. Russell, eds. 1978). In the British-American environment, the article Literature and Ecology: An Experiment in Ecocriticism by the founder of global ecocriticism, William Rueckert, was published in 1978. Even earlier than that, in 1974, the technical term "literary ecology" was introduced by Joseph W. Meeker in his book The Comedy of Survival: Studies in Literary Ecology, in which he provided an ecological aspect on reading literature. A broader perspective on deep ecology was provided by the French researcher Luc Ferry with his work Le nouvel ordre écologique (The New Ecological Order, 1992). On the basis of literary ecology and the book Green Cultural Studies: Nature in Film, Novel, and Theory, by Jhan Hochman (1998), "green cultural studies" were established. Ecological literary studies later also spread to Germany, but not until very recently (e. g. Peter Finke, Kulturökologie [Cultural Ecology], 2003; and Hubert Zapf, Literatur als kulturelle Ökologie [Literature on Cultural Ecology]). In the 1970s, 1980s and 1990s, various scholarly associations around the world brought together researchers that studied animals, plants, and nature or the natural environment from various perspectives. These included the association Nature, Legend and Story, in which researchers study animals and nature from the perspectives of folklore, myth, and literature (initiated by Boria Sax and founded in 1997). After 2001 we saw the beginnings of a scholarly field called critical animal studies. The foundations of its scholarly theory were established by Steven Best and Anthony J. Nocella, who founded ICAS, the Institute for Critical Animal Studies in 2001 and an interdisciplinary journal, Animal Liberation Philosophy and Policy Journal, which became the Journal for Critical Animal Studies in 2003. The journal was the first to critically approach the topic of animals as a political issue. The same year a collection of scholarly papers The Animal Ethics Reader (Armstrong and Botzler 2003) was published. ${ }^{18}$ The $21^{\text {st }}$ century has seen dramatic changes in the attitude towards the world and new awareness of the position of humans and their role in relation to nature and non-human species. All authors brought fresh points of view from within various social sciences, and sought new ways to approach theoretical and empirical research on the relationship between the human and the animal. As it was not possible to find an appropriate theoretical and methodological basis within ethnology and folklor-

${ }^{18}$ Compare with Humanimalia magazine (internet source 2) which also publishes texts on the human-animal relationship in literature, culture, society. (see Humanimalifesto. The Purpose of Humanimalia. Humanimalia, ajournalofhuman/animalinterface studies;http://www.depauw.edu/humanimalia/ humanimalifesto.html.) 
istics, social science researchers who explored animals and their positions and roles in human societies chose different types of theoretical discourses. Consequently, they searched for appropriate terminology and disciplines within which they could research the roles and significance of animals in culture and the relationship between humans and animals. In Croatia, three possible names for the new discipline emerged, i.e. cultural animal studies, animal anthropology and radical literary animal studies. ${ }^{19}$ Only after 2009, did the term "zoofolkloristics" come into use, ${ }^{20}$ and it is now well established in Croatian ethnology and anthropology. Based on the research project called Cultural Animal Studies, the ethnologists Antonija Zaradija Kiš and Suzana Marjanić edited two collections of scholarly papers $(2007,2012)$ in which the contributing authors discuss animals in folklore, literature and culture. Until then, research placing animals at their centre had been marginal and discussed from an anthropocentric position only. These two collections highlighted the ecocentric and zooethtical views. In Estonia, the expression zoofolkloristics dates back to 2004, when researchers at the University of Tartu and The Estonian Folk Museum in Tartu started a project named Zoofolkloristics. ${ }^{21}$ Research within the project, based on Tim Ingold's discourse, looks at animals in folklore, in everyday proverbs and sayings (e.g. cats and dogs), and in archaeology. In Slovenia, even though zoofolkloristics ${ }^{22}$ is in its inception, we have been aware of animals in folklore ever since folkloristics was first established as an independent discipline. However, in song folklore research at least, there has not been any interest in complex analyses. ${ }^{23} \mathrm{We}$

${ }^{19}$ Marjanić believes that a sentimental attitude towards animals should be separated from a zooethical one (Marjanić 2006: 175). Sentimental and empathetic attitudes towards animals can be found in Slovenian folklore and literary practice, while zoo-ethical attitudes are represented in contemporary Slovenian poetry. An example of zoo-ethical attitude in world literature is Richard Adams' novel Plague Dogs (1977), and before that there was Mark Twain's A Dog's Tale (1904). Both narratives criticise vivisection and animal torture. In Slovenia the sentimental attitude towards animals can be found in the works of Ivan Cankar.

${ }^{20}$ See Pregled bibliografske jedinice broj: 642658. Hrvatska znanstvena bibliografija, 19. 9. 2013; https://bib.irb.hr/prikazi-rad?\&rad=642658.

${ }^{21}$ See Zoofolkloristics. Estonian Folklore, The Department of Folkloristics of the Estonian Literary Museum. http://en.folklore.ee/rl/fo/activ/en_zoof.htm.

${ }^{22}$ Between 2009 and 2015 zoofolkloristics was introduced among European and American folklorists and anthropologists when it was discussed at individual symposiums in Ljubljana 2009, when the term zoofolkloristics was first used; Lisbon 2011; Santa Fe 2014). The concepts of zoofolkloristics will be presented in Zagreb 2015 in a special panel dedicated to animals in/ as heritage (see as an example: Panels/Workshops. SIEF, International Society for Ethnology and Folklore, 11. 12. 2010; http://www. nomadit.co.uk/sief/sief2011/panels.php5?PanelID=755). The author of this article aims to establish this discipline in Slovenia. We can observe that other human sciences are beginning to consider the relationship between animals and people as well as anthropology and folklore studies, e.g. history (Kleinberg 2013), archaeology, musicology (Sorce Keller 2012) and others. The highest number of discussions and monographs were published in the field of philosophy as well as in sociology and law.

${ }^{23}$ In Slovenia, Monika Kropej intensively investigated animal world in folk storytelling, but from a classical standpoint looking into symbolism, motifs and themes, and mostly from the perspective of mythology. Mirjam Mencej uses a similar approach, she has specifically looked at the wolf in mythology, 
are now undoubtedly looking at a change in paradigm, the rejection of Western duality and the adoption of new paradigms where humanity is no longer at the top of the hierarchy of living beings, and is willing to accept animals in their inherence. ${ }^{24}$

\section{REFLECTIONS ON THE METHODOLOGY, THEORY AND DIRECTIONS IN ZOOFOLKLORISTIC RESEARCH}

Zoofolkloristic methods of research include a joint diachronic and synchronic methodological approach. The implementation of individual folkloristic, ethnological and anthropological methodological approaches as well as methods of ecocriticism are essential. Zoofolkloristic and zoo-literary theory methods, transdisciplinary method of critical discourse analysis (Fairclough 2010), ecocriticism (Glotfelty 1996; Golež Kaučič 2011a) and cultural ecology (Hofer 2007; Zapf 2008) enable us to identify and analyse areas of song and narrative creativity that reflect anthropocentric and anthropomorphic attitudes towards animals and the animal world as expressed through folklore. This would help us establish a complex network of data in the area where the findings from folklore and literature merge with the culture of non-human subjectivity and provide a transformative view on the interaction between nature and culture. Proceeding from the folklore-literature-culture-ecologyethics paradigm and the basic interconnection and influence of individual structures of the paradigm, ecofolklore, ecoliterature, and ecoculture should connect this paradigmatic structure as reintegrational interdiscourse with cognitive unification and interaction of separate worlds and views. They should also introduce new or uniform terminology and a new ethical model of society and culture.

New findings from the field, complementing the diachronic perspective towards research, as well as theoretical analytical discourse, should enable an insight into changes in human attitudes towards animals and plants in both folklore and literary texts as well as within traditional and modern ritual practices. Field research should foster an understanding of both past and present views of animals in rural and urban spaces. Furthermore, it should determine its informants' reception and interpretation of folk tradition. With the help of updated questionnaires we could establish what kind

although this research does not extend to the so-called ontological turn. However, she says that "besides anthropologists, folklorists too can discover various constructions and consolidations of reality" (Mencej 2007: 149).

24 "Animals, the awareness of their mien: to lift from uncertainty, dark confusion. Only the animal itself can sense its own mien, which is a secret they will take with them when they die. No one can sense an animal as it does itself!" (Detela 2011: 81). 
of conditions animals in both the countryside and in urban areas live in, the differences in their treatment and understanding as well as the changes that happened since the change in the Slovenian political system. Studies of animals in folklore are both classical and innovative. Therefore, this type of animal research, which does not have a critical discourse just yet, could be classified into the following sets: classical, from the perspective of the human as a superior (dealing with motifs and themes, metaphorical study of animals); mythological research into symbolic images of animals; ethnological research into the practical use of animals and their products; animals in beliefs and folk medicine, the animal folklore of both urban spaces and the countryside in modern texts. ${ }^{25}$ We need to continue by presenting animal research and including critical discourse analyses based on the merging of at least three areas of social sciences. This would develop into a new interdisciplinary study through the introduction of new terminology and a innovative intersection of theoretical and methodological discourses. These studies are: cultural animal studies, animal "anthropology" and critical animal studies.

We cannot say that cultural animal studies is true zoo-ethics; it includes various types of research into animals in folklore, culture, literature. On the other hand, animal "anthropology" is closely connected to the criticism of human attitudes towards animals. It is the answer to cultural anthropology, which deals with the human as a cultural animal (Havilad 2004: 8), but in its expression it is actually a paradox. Finally, critical animal studies reject exclusively academic discourse and introduce active socio-political actions. ${ }^{26}$

\section{THE REDEFINITION OF FOLKLORISTIC FINDINGS AND THE GOALS OF ZOOFOLKLORISTICS}

Zoofolkloristics should enable a distinct paradigmatic change transitioning from the role and significance of animals into the redefinition of tradition. This would permit a change in viewing animals as objects to seeing them as persons. Moreover, it could bring to the fore positive examples of the co-existence of both entities not only on the metaphorical, symbolic and mythological levels but also by looking at relationships testified by people who co-existed with animals in the reality and are reflected in folk songs,

\footnotetext{
${ }^{25}$ This refers to stories or tales of animals created in modern times that reflect real interactions between people and animals today, e.g. articles in various newspapers and journals, or those that are orally transmitted (see Bokal 2007).

${ }^{26}$ During his lecture at the University in Maribor in 2011, Steven Best called for further active struggle to preserve the natural environment and to stop the holocaust of animals (see University of Maribor, Slovenia Poster and Photo SlideShowDr.SteveBest, 9. 10. 2011; http://drstevebest.wordpress. com/2011/10/09/university-of-maribor-slovenia-poster-and-photo-slide-show/).
} 
narratives, legends, customs and beliefs. For this reason, the reader's or listener's "empathetic identification" with the Other, in this case with animals, is an imperative. Literary and folkloric texts enable a transition from anthropocentrism to ecocentrism with a new emphasis on the content and messages they bring and require new readings/listening and interpretations. According to Veber (Veber 1985: 351-352) each new reading or adequate reception of literary or folkloric works and traditions includes emotion or experiencing the text. The recipient reading a work includes in their reception their immanent personality with the sum of its personal and theoretical bases, knowledge and preferences. The reader/listener who is also the researcher equips paradigmatically their experience with goals that, at the end of reading/listening, they try to present to the recipients of their own work. It is especially symptomatic in cases where a researcher wishes to study established texts, rigidly limited by genre, using new theories. The aim is to create a new ecological-ethical-empathetic axis of reading which might affect a change to a view where an animal subject is no longer an object, but a person. Indirectly, we wish to facilitate the end of harmful traditional cultural practices in human interaction with animals, to point out that animals are not human possessions and finally to facilitate a shift from the paradigm of exploitation to the paradigm of equal co-existence with non-human subjectivity and from speciesism to non-speciesism.

The research done within the frameworks of zoofolkloristics (ethnozoology, ecocriticism) could affect the legal certainty of non-human subjective entities (animals, plants, an environment), reactivating a positive tradition and redefining the negative one. Thus we expand into the field of the so-called social anthropology, where the zoo- prefix could provide legitimacy to its research by using the paradigm of critical assessment of tradition and subsequently affect the upholders of these traditions to reconsider and eventually drop them. This, for example, happened when the practice of catching birds in Ljubljana was abandoned. Birds were caught using a special musical instrument called a čivink. Nowadays the čivink is but a souvenir - no one would even think of catching birds, whether using a čivink or birdlime (see Smerdel 1992; Škofic 2001) - which represents an "interesting pass time" and ends in captivity or death for the birds. ${ }^{27}$ This practice only ended because it was banned, and even then the ban was often violated. It is clear however, that some practices are connected with their persistent ${ }^{28}$ use. Without any reflection, animals are used for food, clothing or something else despite the fact

\footnotetext{
${ }^{27}$ See Ptičji lov, ptičarstvo (The bird hunt) Slovenski etnografski muzej; http://www.etno-muzej.si/sl/ spletne-zbirke/klasifikacije/pticji-lov-pticarstvo.

${ }^{28}$ Birds used to be considered pests in orchards and in fields, which justified bird hunting. Later, the perception of birds changed and bird hunting was banned (see Smerdel 1992). However, practices such as slaughtering pigs (regardless of the considerable change in attitudes towards pigs, who are now seen
} 
that they are not necessarily essential for human survival since many alternatives are available. Whenever animals appear in folklore or in broader folk culture, zoofolkloristics, as well as ethnozoologists and "ecoethnologists", can shed light on their roles and significance. The expression "ecocultural studies" and "green studies" could consequently be established as a common expression for all movements within the discourse of culture and ecology. In the same way in which biodiversity is now an established expression in natural sciences, we could introduce the expression "ecocultural diversity" which would follow the legitimising of moral and ethical findings to abolish human dominance over non-human living, subjective entities. This is also connected with the introduction of a new and uniform terminology.

The introduction of this new discipline aims to redefine some negative cultural practices, which exploit the myth of human superiority in order to deny subjectivity to co-existing entities and to nature. Furthermore, non-human subjective entities are being destroyed under the principle of dominance. Zoofolkloristics cannot become merely an academic discipline, and not actively affect the socio-political composition of the environment where the human and non-human subjective entities co-exist. Therefore, the purpose of zoofolkloristic research, articles and other work is to form the so-called scientific ethical preamble to a possible new law on the protection of animal rights. ${ }^{29}$ Moreover, we should create an "ecocatalogue", simultaneously enumerating both the negative and the positive traditional and cultural practices ${ }^{30}$ based on the accepted ethical preamble. Following the changes in the modern world, new insights and different perceptions of animals, plants and nature, positive folkloric knowledge or folklore wisdom needs to be introduced into Slovenian and European reality, while negative traditions should be abolished.

as intelligent beings), and the unnecessary use of meat for food for survival - this is not a basic need anymore, but the need to satisfy the sense of taste.

${ }^{29}$ The scientific-ethical preamble which could be drawn up by all disciplines that have or have not yet added the prefix eco (although this prefix has often been exploited and it is, for example, inexcusable to use it to label the flesh of killed animals as eco) could considerably change human attitudes towards animals and could become one of the cornerstones of a future legal preamble or even legislation on the civil rights of animals as persons (see Donaldson in Kymlicka 2011; Francione 2008).

${ }^{30}$ An example of negative traditional practices is dormice hunting and an example of negative contemporary practices is donkey racing as new ways of entertainment and cultural practice. An example of a positive practice is helping frogs during their spring migration. At a time when, in Slovenia for example, not a single animal has to die for food necessary for the survival of humans it is an imperative to change any tradition that propagates meat-eating. Why should kranjska klobasa, for example, a sausage made from animal carcases enjoy the protection of cultural heritage even within the European Union? 


\section{REFERENCES AND SOURCES}

Adams, Richard. [1972] 1984. Watership Down. Harmondsworth: Penguin Books.

Adams, Richard. 1977. The Plague Dogs. London: Allain Lane.

Agamben, Giorgio. 2004. The Open. Man and Animal. California: Stanford University Press.

Armstrong, Suzane J. and Richard Botzler. 2003.The Animal Ethics Reader. London, New York: Routledge.

Bakewell, Sarah. 2014. Kako živeti ali Življenje Michela du Montaigna z enim vprašanjem in dvajsetimi odgovori. Novo mesto: Penca in drugi d. n. o.

Balée, William and J. Christopher Brown. 1996. "Ethnobotany". In Encyclopedia of Cultural Anthropology. David Levinson and Melvin Ember, eds. New York: New York: Henry Holt \& Co., 399-404.

Behnke, Elisabeth A. 1999. "From Merleau-Ponty's Concept of Nature to an Interspecies Practice of Peace". In Animal Others. On Ethics, Ontology, and Animal Life. H. Peter Steeves, ed. New York: Albany State University of New York Press, 93-117.

Berlin, Brent. 1992. Ethnobiological Classification. Principles of Categorization of Plants and Animals in Traditional Societies. Princeton: Princeton University Press. [http://dx.doi. org/10.1515/9781400862597]

Best, Steven. 2014. "The Rise of Critical Animal Studies. Putting Theory into Action and Animal Liberation into Higher Education". State of Nature, an Online Journal of Radical Ideas, Summer 2009. Available at: http://www.stateofnature.org/?p=5903\#sthash.NwhwbvmT. dpuf (accessed 20 January 2014).

Bokal, Ljudmila. 2007. "Srečanje z malo miško". Planinski vestnik 107/10: 4-25.

Botkin, Daniel. 2006. "The Folklore behind Ecology, or Why Scientists of Ecology Need Help from Folklorists". The American Folklife Center, 5. 4. 2006. Available at: http://www.loc. gov/folklife/events/BotkinArchives/2006PDFandVideo/BotkinFlyer.pdf (accessed 12 September 2013).

Cambi, Nenad and Nikola Visković, eds. 1999. Kulturna animalistika. Zagreb: Institut za etnologiju i folkloristiku, Hrvatska sveučilišna naklada.

Calarco, Matthew, ed. 2008. Zoographies. The Question of the Animal from Heidegger to Derrida. New York: Columbia University Press.

Cavell, Stanley, Cora Diamond, John McDowell, Ian Hacking and Cary Wolfe. 2008. Philosophy and Animal Life. New York: Columbia University Press.

Clutton-Brock, Juliet. 2006. "The Unnatural World. Behavioural Aspects of Humans and Animals in the Process of Domestication". In Animals and Human Society. Changing Perspective. Aubrey Manning and James Serpell, eds. London, New York: Routledge, 23-36.

Čeh Steger, Jožica. 2010. "Ekološko usmerjena literarna veda in Prežihove samorastniške novele". Jezik in slovstvo 55/3-4: 53-62.

Darwin, Charles. 1872. The Expression of the Emotions of Man and Animals. London: John Murray.

Deleuze, Gilles and Felix Guattari. 2000. Micelij. (Mille plateaux). Koper: Hyperion.

Derrida, Jacques. 1991. "'Eating Well' or the Calculation of the Subject. An Interview with Jacques Derrida". In Who Comes After the Subject? Connor and Nancy Cadava, eds. New York, London: Routledge, 96-119.

Derrida, Jaques. 2002. “The Animal That Therefore I am”. Critical Inquiry 28: 369-418. [http:// dx.doi.org/10.1086/449046] 
Detela, Jure. 2011. Orfični dokumenti, 1. Teksti in fragmenti iz zapuščine. Koper: Hyperion.

Donaldson, Sue and Will Kymlicka. 2011. Zoopolis. A Political Theory of Animal Rights. Oxford: Oxford University Press.

Dunayer, Joan. 2001. Animal Equality. Language and Liberation. Derwood: Ryce Publishing.

Dunayer, Joan. 2009. Specizam. Diskriminacija na osnovi vrste. Zagreb, Čakovac: Institut za etnologiju i folkloristiku, Dvostruka duga.

Dunlap et al. 2000. "Measuring Endorsement of the New Ecological Paradigm. A Revised NEP Scale". Journal of Social Issues 56: 3. [http://dx.doi.org/10.1111/0022-4537.00176]

Fairclough, Norman. 2010. Critical Discourse Analysis. The Critical Study of Language. Harlow etc.: Longman.

Ferry, Luc. 1998. Novi ekološki red. Drevo, žival in človek. (Le nouvel ordre écologique. L'arbre, L'animal et l'homme). Ljubljana: Založba Krtina.

Finke, Peter. 2003. "Kulturökologie". In Konzepte der Kulturwissenschaften. Theoretische Grundlagen - Ansätze - Perspektiven. Vera Nünning and Ansgar Nünning, eds. Stuttgart, Weimar: Metzler, 248-279.

Francione, Gary L. and Anna E Charlton. 1992. Vivisection and Dissection in the Classroom. A Guide to Conscientious Objection. American Anti-Vivisection Society.

Francione, Gary L. 2000. Introduction to Animal Rights (Your Child or the Dog?). Philadelphia: Temple University Press.

Francione, Gary L. 2008. Animals as Persons. Essays on the Abolition of Animal Exploitation. New York: Columbia University Press.

Glotfelty, Cheryll. 1996. "Introduction. Literary Studies in an Age of Environmental Crisis". In The Ecocriticism Reader. Landmarks in Literary Ecology. Cheryll Glotfelty and Harold Fromm, eds. Athens, London: The University of Georgia Press, 15-37.

Godina Golija, Maja. “Koline”. Etnološki leksikon. Ljubljana: Mladinska knjiga, 224-225.

Golež Kaučič, Marjetka. 2002a. "'Animals Bury the Hunter'. Ethical and Sociological Elements of the Slovene Ballad". Acta ethnographica Hungarica 47/1-2: 163-174. [http://dx.doi. org/10.1556/AEthn.47.2002.1-2.17]

Golež Kaučič, Marjetka. 2002b. “Živalske pripovedne pesmi - vloga in pomen živalskih podob”. Traditiones 31/2: 23-42.

Golež Kaučič, Marjetka. 2004. "The Blackbird Mocks the Hunter. Human and Animal Relationships in Slovene Animal Ballads". In Ballads and Diversity. Perspectives on Gender, Ethos, Power and Play. Isabelle Peere and Stefaan Top, eds. Trier: WV Wissenschaftlicher Verlag, (B-A-S-I-S; 1), 127-136.

Golež Kaučič, Marjetka. 2011a. "Folklorni in živalski slovar v ustvarjalnem opusu Svetlane Makarovič”. Jezik in slovstvo 56/1-2: 31-48.

Golež Kaučič, Marjetka. 2011b. "Thematization of Nonhuman Subjectivity in Folklore, Philosophical, and Literary Texts". Cosmos 27: 121-154.

Golež Kaučič, Marjetka. 2012a. “'Čovjek je najgora zvijer'. Životinjski svijet u slovenskom usmenom pjesništvu i suvremenoj slovenskoj poeziji”. In Književna životinja, 2. Kulturni bestijarij. Suzana Marjanić and Antonija Zaradija Kiš, eds. Zagreb: Hrvatska sveučilišna naklada, Institut za etnologiju i folkloristiku, 957-993.

Golež Kaučič, Marjetka. 2012b. "Fantje so goljufivi kot škorpijoni. Kače in škorpijoni v slovenski folklori in poeziji". In Guje i jakrepi. Književnost, kultura. Mirjana Detelić and Lidija Delić, eds. Beograd: Balkanološki institut SANU, 301-322. 
Golež Kaučič, Marjetka. 2013a. "Riba Faronika. Bitje voda in sveta v izročilu in v sodobnih interpretacijah". In Aquatica. Književnost, kultura. Mirjana Detelić and Lidija Delić, eds. Beograd: Balkanološki institut SANU, 263-281.

Golež Kaučič, Marjetka. 2013b. “'A Bunny is a Beautiful Thing' or Animals as Machines (!?). The Perception of the Animal World in Slovenian Folk Songs". Traditiones 42/1, 42: 71-88.

Grčevič, Franjo. 2002. Simbolizam, ekologija, eshatologija. Zagreb: Matica hrvatska.

Haviland, William A. [1975] 2004. Kulturna antropologija. Jastrebarsko: Naklada Slap.

Hochman, Jhan. 1998. Green Cultural Studies. Nature in Film, Novel, and Theory. Moscow, Idaho: University of Idaho Press.

Hobgood-Oster, Laura. 2007. "Holly Dogs and Asses. Stories Told through Animal Saints". In What Are the Animals to Us? Approaches from Science, Religion, Folklore, Literature, and Arts. Dave Aftandilian, ed. Knoxville: The University of Tennessee Press, 189-205.

Hofer, Stefan. 2007. Die Ökologie der Literatur. Bielefeld: Transcript Verlag.

Humanimalifesto. "The Purpose of Humanimalia". Humanimalia, a journal of human/animal interface studies. Available at: http://www.depauw.edu/humanimalia/humanimalifesto. html (accessed 21 March 2014).

Hösle, Vittorio. 1996 (1991). Filozofija ekološke krize. Moskovska predavanja. Zagreb: Matica hrvatska.

Ihvanus-s-Safa. 2008. Razgovor čovjeka sa životinjama. Zagreb: V. B. Z.

Ilomäki, Henni. 2002. "Animals in People's Mind and in the Language of Folklore". Folklore. Electronic Journal of Folklore 21. Available at: http://www.folklore.ee/folklore/vol21/ animals.pdf, doi: 10.7592/FEJF2002.21.animals (accessed 10 February 2014). [http:// dx.doi.org/10.7592/FEJF2002.21.animals]

Ingold, Tim, ed. 1994. What is an Animal? One World Archaeology, 1. London, New York: Routledge.

Ingold. Tim. 2000. Companion Encyclopedia of Anthropology, Humanity, Culture and Social Life. London, New York: Routledge.

James, Rachel. 1997. Can Ethics Provide Answers? Lanham, Boulder: Rowman and Littlefield.

Joy, Melanie. 2010. Why We Love Dogs, Eat Pigs, and Wear Cows. An Introduction to Carnism. San Francisco: Conari Press.

Kalof, Linda and Amy Fitzgerald, eds. 2007. The Animal Reader. The Essential Classic and Contemporary Writings. Oxford, New York: Berg.

Klampfer, Friderik. 2010. Cena življenja. Razprave iz bioetike. Ljubljana: Krtina.

Kleinberg, Ethan, ed. 2013. History and Theory. Studies in the Philosophy of History. Does History Need Animals? 52/4.

Kropej, Monika. 2011. Živalska govorica. Slovenske basni in pripovedi o živalih. Radovljica: Didakta.

Kuhn, Thomas. S. [1962] 2012. The Structure of Scientific Revolution. Chicago: University Press. [http://dx.doi.org/10.7208/chicago/9780226458144.001.0001]

Kuret, Niko. 1989. Praznično leto Slovencev, 1, 2. Ljubljana: Družina.

Lévi-Strauss, Claude. 1994. Rasa in zgodovina. Totemizem danes. Ljubljana: Škuc, Znanstveni inštitut Filozofske fakultete.

Lockwood, Randall. 1989. "Anthropomorphism is not a Four-letter Word". In Perceptions of Animals in American Culture. R. J. Hoage, ed. Washington: Smithsonian Institution, 41-56. 
Marjanić, Suzana. 1999. "Krležine davno-dnevno-dnevničke zoometafore". In Kulturna animalistika. Nenad Cambi and Nikola Visković, eds. Institut za etnologiju i folkloristiku, Hrvatska sveučilišna naklada.

Marjanić, Suzana. 2006. "Književni svjetovi s etnološkom, ekološkom i animalističkom nišom”. Narodna umjetnost 43/2: 163-186.

Marjanić, Suzana and Antonija Zaradija Kiš, eds. 2007. Kulturni bestijarij, 1. Zagreb: Hrvatska sveučilišna naklada, Institut za etnologiju i folkloristiku.

Marjanić, Suzana and Antonija Zaradija Kiš, eds. 2012. Književna životinja. Kulturni bestijarij, 2. Zagreb: Hrvatska sveučilišna naklada, Institut za etnologiju i folkloristiku.

Marjanić, Suzana. 2012. "Zoosfera Tita Andronika. Ljudska, odviše ljudska bestijalnost”. In Književna životinja. Kulturni bestijarij, 2. Suzana Marjanić and Antonija Zaradija Kiš, eds. Zagreb: Hrvatska sveučilišna naklada, Institut za etnologiju i folkloristiku, 542-544.

Meeker, Joseph W. 1974. The Comedy of Survival. Studies in Literary Ecology. New York: Scribner's.

Mencej, Mirjam. 2007. "Uloga predaje o gospodaru vukova u strukturi ljetnog ciklusa". In Kulturni bestijarij, 1. Suzana Marjanić and Antonija Zaradija Kiš, eds. Zagreb: Hrvatska sveučilišna naklada, Institut za etnologiju i folkloristiku, 149-166.

Montaigne, Du Michel. 1960. Eseji. Ljubljana: Mladinska knjiga.

Nietzsche, Friedrich. Somrak malikov. Primer Wagner. Ecce homo. Antikrist. Ljubljana: Slovenska matica.

Noske, Barbara. 1993. Humans and Other Animals. Beyond the Boundaries of Anthropology. London: Pluto.

Olusola, Ajibade George. 2005. "Animals in the Traditional Worldview of the Yorùbá". Folklore. Electronic Journal of Folklore 30. Available at: http://www.folklore.ee/folklore/vol30/ olusala.pdf. doi:10.7592/FEJF2005.30.olusala (accessed 10 February 2014). [http:// dx.doi.org/10.7592/FEJF2005.30.olusala]

Orwel, George. 1945. Animal Farm. London: Secker and Warburg.

Panels/Workshops. SIEF, International Society for Ethnology and Folklore, 11. 12. 2010. Available at: http://www.nomadit.co.uk/sief/sief2011/panels.php5?PanelID=755 (accessed 10 February 2014).

Porter, James Roy and William Moy Stratton Rusell. 1978. Animals in Folklore. Ipswich: Rowman and Littlefield for Folklore Society.

“Pregled bibliografske jedinice broj: 642658". Hrvatska znanstvena bibliografija, 19. 9. 2013. Available at: https://bib.irb.hr/prikazi-rad?\&rad=642658 (accessed 2 April 2014).

"Ptičji lov, ptičarstvo (The bird hunt)". Slovenski etnografski muzej. Available at: http://www. etno-muzej.si/sl/spletne-zbirke/klasifikacije/pticji-lov-pticarstvo (accessed 27 March 2014).

Regan, Tom. 1983. Case for Animal Rights. Berkeley, Los Angeles: University of California Press.

Ryder, Richard D. 2000. Animal Revolution. Changing Attitudes towards Specieciesism. London, New York: Bloomsbury Academic.

Rueckert, William. 1978. "Literature and Ecology. An Experiment in Ecocriticism". Iowa Review 9/1: 71-86.

Sax, Boria. 1998. The Serpent and the Swan. The Animal Bride in Folklore and Literature. Blacksburg, Virginia: The McDonald and Woodward Publishing Company. 
Sax, Boria. 2007. "Animals as Tradition". In The Animals Reader. The Essential Classic and Contemporary Writings. Linda Kalof and Amy Fitzgerald, eds. Oxford, New York: Berg, 270-278.

Serpell, James. 1996. In the Company of Animals. Cambridge: Cambridge University Press.

Shepard, Paul. 1978. Thinking Animals. Animals and the Development of Human Intelligence. New York: Viking.

Smerdel, Inja. 1992. "Med smrtjo na krožniku in ječarsko ljubeznijo ali o ptičjem lovu v Brdih". Etnolog 2/1: 29-78.

Smerdel, Inja. 2005. “'Bol si pameten ku človk, je rekel volu?' O razmerju človek - vol v vsakdanu in kulturi pivškega kmeta". In Slavenski zbornik. Janko Boštjančič, ed. Vrhnika: Galerija 2, 431-379.

Slovar slovenskega knjižnega jezika, 5. 1991. Ljubljana: Državna založba Slovenije.

Sorce Keller, Marcello. 2012. "Zoomusicology and Ethnomusicology. A Marriage to Celebrate in Heaven". Yearbook for Traditional Music 44: 166-183. [http://dx.doi.org/10.5921/ yeartradmusi.44.0166]

Steiner, Gary. 2005. Anthropocentrism and its Discontents. The Moral Status of Animals in the History of Western Philosophy. Pittsburgh Press.

Škofic, Jožica. 2001. "O ptičjem lovu in ptičarstvu po kroparsko". Slovenski jezik - Slovene linguistic studies 3: 135-168. Available at: https://kuscholarworks.ku.edu/dspace/ bitstream/1808/822/1/308Skofic.pdf (accessed 3 April 2014).

Štuva, Sara. 2013. “Dialog Antropologije z etiko živali (Vloga živali znotraj antropologije)”. Annales 23/1: 133-144.

Tapper, Richard. 1994. "Animality, Humanity, Morality, Society". In What is an Animal? Tim Ingold, ed. London, New York: Routledge, 47-60.

Taylor, Paul. 1986. Respect for Nature. A Theory of Environmental Ethics. Princeton: University Press.

Twain, Mark. 1904. The Dog's Tale. New York: Harper Brothers.

"University of Maribor, Slovenia Poster and Photo Slide Show. Dr. Steve Best", 9. 10. 2011. Available at: http://drstevebest.wordpress.com/2011/10/09/university-of-maribor-slovenia -poster-and-photo-slide-show/ (accessed 3 April 2014).

Veber, France. 1985. Estetika. Ljubljana: Slovenska matica.

Vičar, Branislava. 2011. "Moralna vrednost živali v diskurzu biotske raznovrstnosti". In Meddisciplinarnost $v$ slovenistiki. Simona Kranjc, ed. Ljubljana: Znanstvena založba Filozofske fakultete, Obdobja, Simpozij = Symposium 30: 509-514.

Vičar, Branislava. 2013. "Primerjava zagovora živali v Plutarhovi razpravi 0 uživanju mesa in v Shelleyevem Zagovoru naravne prehrane”. Keria 15/1: 133-147.

Visković, Nikola. 1996. Životinja i čovjek. Prilog kulturnoj zoologiji. Split: Književni krug.

Visković, Nikola. 2001. Stablo i čovjek. Prilog kulturnoj botanici. Zagreb: Antibarbarus.

Visković, Nikola. 2009. Kulturna zoologija. Zagreb: Naklada Jesenski i Turk.

Viveiros de Castro, Eduardo. 1998. "Cosmological Deixis and Ameridian Perspectivism". Journal of the Royal Anthropological Institute 4/3: 469-488. [http://dx.doi.org /10.2307/3034157]

Zapf, Hubert. 2002. Literatur als kulturelle Ökologie. Zur kulturellen Funktion imaginativer Texte an Beispielen des amerikanischen Romans. Tübingen: Max Niemeyer. 
Zapf, Hubert, ed. 2008. Kulturökologie und Literatur. Beiträge zu einem transdisziplinären Paradigma der Literaturwissenschaft. Heidelberg: Universitätsverlag Winter.

"Zoofolkloristics". Estonian Folklore, The Department of Folkloristics of the Estonian Literary Museum. Available at: http://en.folklore.ee/rl/fo/activ/en_zoof.htm (accessed 26 March 2014).

Willis, Roy, ed. 1990. Signifying Animals. Human Meaning in the Natural World. New York: Routledge.

\section{ZOOFOLKLORISTIKA: PRVI UVIDI NA PUTU PREMA NOVOJ DISCIPLINI}

Autorica polazi od tvrdnje da su potrebna nova, kompleksnija istraživanja veza između životinja, prirode i poveznica s ljudima u slovenskoj i europskoj folkloristici, znanosti o književnosti i kulturnim studijima, zbog novih ekoloških i etičkih uvida u širu društveno-kulturnu okolinu i promjene u svijetu, koje su dovele do promjene od antropocentrizma k ekocentrizmu. U radu se na temelju različitih teorijskih diskursa, novih pojmova i multidisciplinarnog znanja stvaraju temelji, smjernice i pravci istraživanja u novoj znanstvenoj disciplini zoofolkloristike. Autorica tvrdi da bi etnologija, folkloristika i znanost o književnosti mogle imati ključnu ulogu u razvoju ekološke svijesti, znanstvenih terenskih istraživanja i kulturne ekologije te tako omogućiti prelazak iz ekologije u eshatologiju. Rad započinje opisom percepcije životinja i odnosa ljudi i životinja, gdje autorica govori o temeljnim pojmovima koji utječu na uvođenje ove nove znanstvene discipline, kao što su: životinja kao ispitanik, individualni pristup životinji, sinantropski i antropofilni pogled na čovjeka i životinju te antropomorfizam. Zatim se govori o povijesnim i suvremenim filozofsko-antropološkim diskursima o ljudskom pogledu na životinju te o teoriji specizma. Autorica razmatra predmet nove discipline te kaže da je u centru istraživanja životinja u folkloru u najširem mogućem smislu, u svim sferama narodne kulture, što se proučava iz novih gledišta, nove percepcije i recepcije; u pjesmama, pričama, bajkama, basnama, predajama, poslovicama, izrekama, zagonetkama, šalama, narodnom jeziku, kulturnim praksama, narodnom teatru, mitologiji, narodnoj medicini pa čak i u narodnoj glazbi. Nadalje, autorica daje pregled kulturnih istraživanja životinja u Europi i Sloveniji, te pokazuje da su rasprave o životinjama uglavnom objavljivane u 21. stoljeću, što bi moglo označavati da je riječ o prelasku u novu paradigmu ili čak i novu ontologiju. Autorica se bavi metodološkim i teorijskim pitanjima i pravcima u zoofolklorističkim istraživanjima koje klasificira prema kritičkom diskursu. Rad završava pregledom ciljeva zoofolkloristike, za koju tvrdi da ne bi smjela postati znanstvena disciplina koja nema aktivan utjecaj na društvenopolitički prostor u kojem koegzistiraju ljudski i ne-ljudski subjektiviteti.

Ključne riječi: zoofolklor, zoofolkloristika, životinje u folkloru i književnosti, antropocentrizam, ekocentrizam, kritički animalistički studiji 